\title{
The New Jersey Margin Scientific Drilling Project (IODP Expedition 313): Untangling the Record of Global and Local Sea-Level Changes
}

Gregory Mountain, Jean-Noël Proust and the Expedition 313 Science Party

doi: 10.2204/iodp.sd.10.03.2010

\section{Introduction}

Much of the world is currently experiencing shoreline retreat due to global sea level rising at the rate of 3-4 $\mathrm{mm} \mathrm{yr}^{-1}$. This rate will likely increase and result in a net rise to roughly $1 \mathrm{~m}$ above present sea-level by the year 2100 (e.g., Rahmstorf, 2007; Solomon et al., 2007), with significant consequences for coastal populations, infrastructures, and ecosystems. Preparing for this future scenario calls for careful study of past changes in sea level and a solid understanding of processes that govern the shoreline response to these changes. One of the best ways to assemble this knowledge is to examine the geologic records of previous global sea-level changes. Integrated Ocean Drilling Program (IODP) Expedition 313 set out to do this by recovering a record of global and local sea-level change in sediments deposited along the coast of eastern North America during the Icehouse

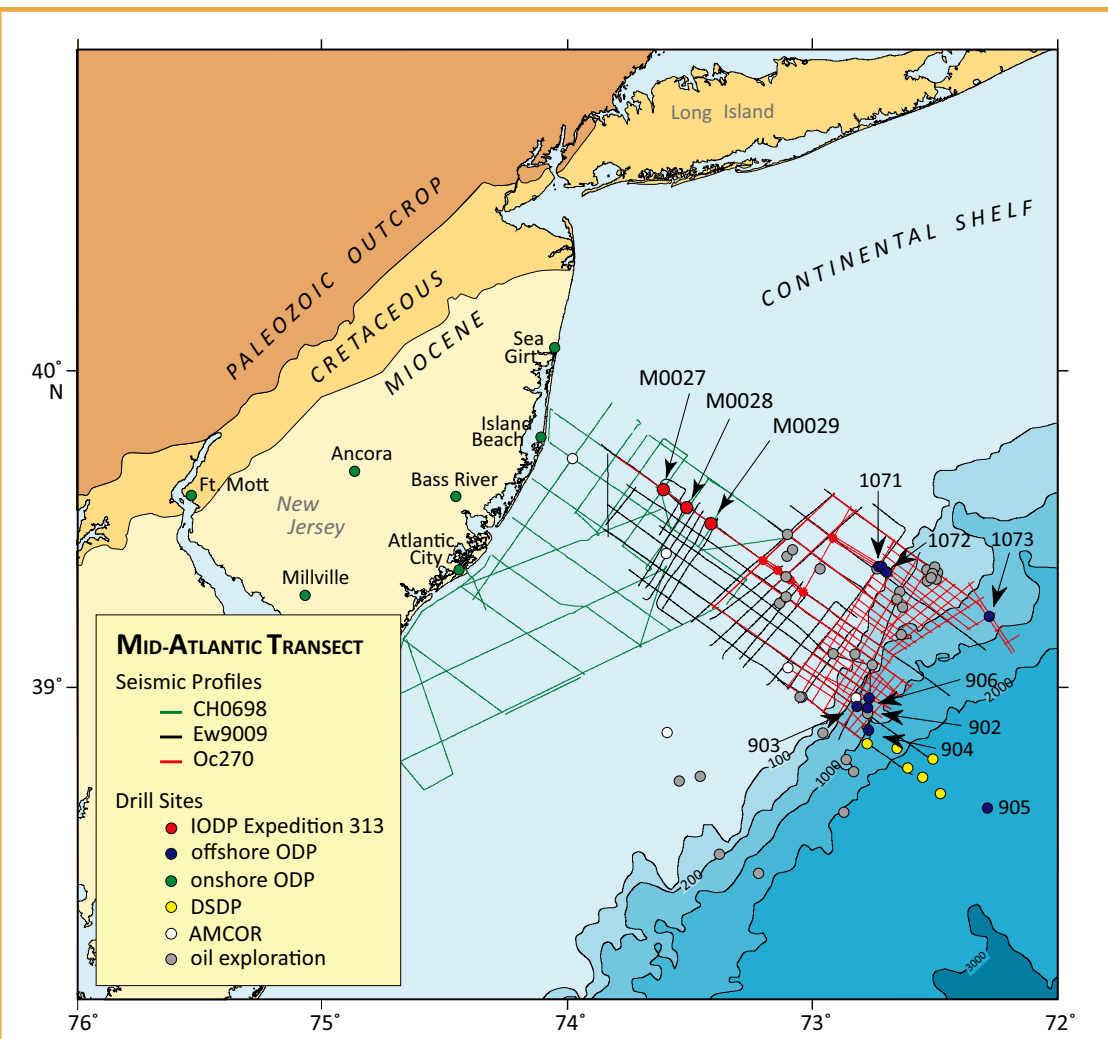

The New Jersey continental margin showing Sites M0027, M0028, and M0029 along with other completed boreholes both onshore and offshore. Tracks of reconnaissance seismic lines relevant to the goals of Expedition 313 are also shown. world of the past 35 m.y. What we learn from this record-the factors driving sea-level changes, and the impact of this change on nearshore environments-will help us understand what lies ahead in a warming world.

Eustatic history can be derived from three archives: corals, oxygen isotopes, and shallow-water marine sediments. Corals provide the most direct and detailed record (millennial-scale resolution or better), but it can be traced back no farther than latest Pleistocene (Fairbanks, 1989; Bard et al., 1996; Camoin et al., 2007). Oxygen isotopic ratios in carbonate-secreting organisms yield a glacio-eustatic proxy, but uncertainties arise further back in time because past water temperatures, which affect the oxygen isotopic ratio of seawater, are not known with sufficient accuracy. Furthermore, changes in the total volume of ocean water as inferred by oxygen isotopes are not the only eustatic drivers; the total volume of the world's ocean basins can change as well and impart eustatic change. For example, variations in the rate of seafloor spreading and in the amount of sediment deposited on the ocean floor affect basin volume and cause long-term ( 10 m.y.) eustatic changes on the scale of tens of meters (Hays and Pitman, 1973; Kominz, 1984; Harrison, 1990) that are not accounted for by oxygen isotopic measurements.

The spatial and temportal arrangement of shallow-water marine sediments is a third archive of eustatic history. Their analysis is not a direct measure like corals, and it is rarely able to track changes at the Milankovitch scale that is possible with oxygen isotopes; however, the shallow marine sedimentary record can detect changes in water depth throughout the Phanerozoic and provide the sum of all processes that contribute to these changes and to the lateral migration of the shoreline. Therein lies the difficulty. Besides responding to eustatic change, the position of the shoreline and the accompanying change in facies respond to changes in sediment supplied to the coastal zone, compaction of deposited sediments, isostatic and/ 
or flexural loading of the crust, thermal subsidence of the lithosphere, and any other vertical tectonic motions of the basin. Furthermore, the magnitude of eustatic change is often considerably smaller than that of these other processes (Watts and Steckler, 1979), making the accurate measurement of this record a very challenging procedure.

Sloss (1963) cited eustasy as a possible cause of continent-wide unconformities dividing successions of shallow-water sediment across North America and Eurasia. His analysis suggested global sea level rose and fell in 100 -m.y. cycles throughout the Paleozoic. Other researchers reported that seismic profiles from sedimentary basins and continental margins revealed additional, globally correlated, unconformity-bound packages that indicated a higher-order cyclicity of eustatic change ( 1.5 m.y.; Vail et al.,

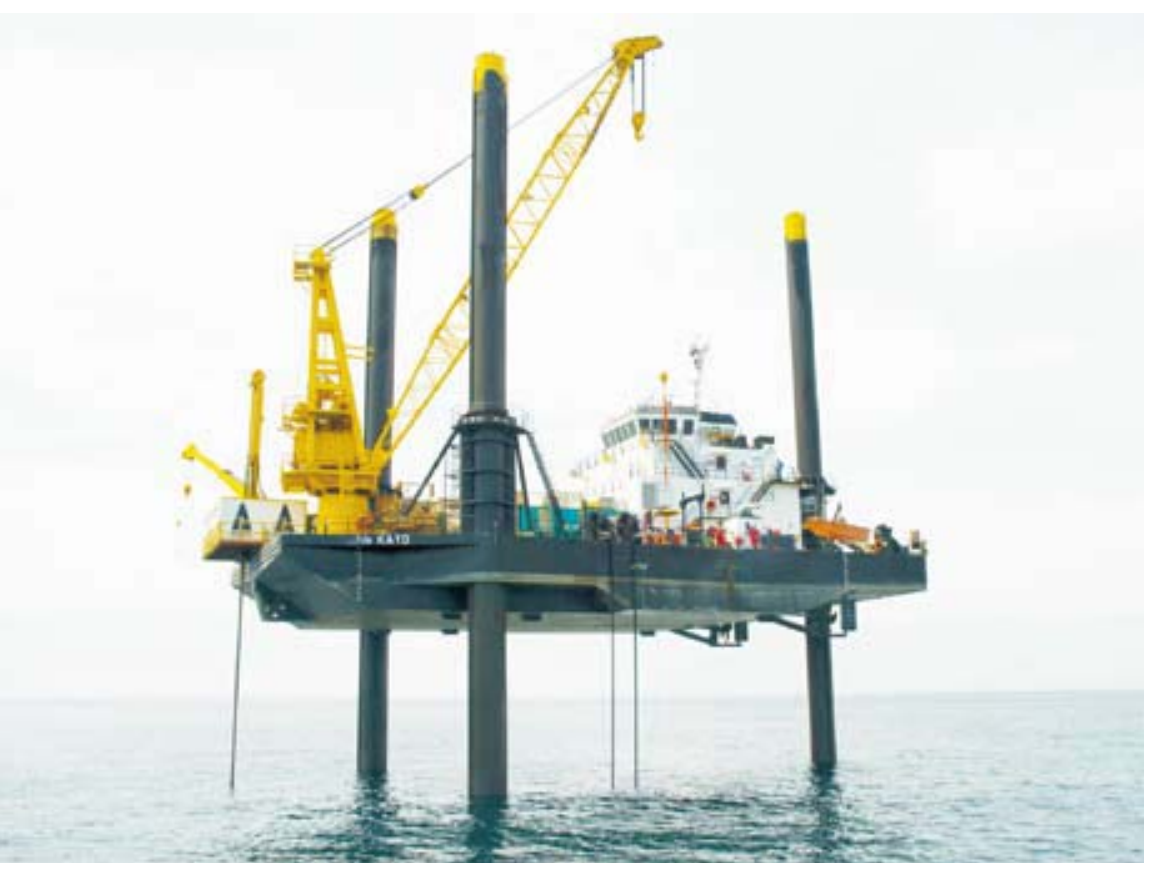

Figure 2. L/B Kayd (Montco Offshore, Inc.) outfitted with a commercial drill rig using coring tools developed and operated by DOSECC, Inc., during Expedition 313 while under direction from ESO. It stands in $35 \mathrm{~m}$ of water $45 \mathrm{~km}$ off the New Jersey coast.
1977). By measuring variations in the

elevation of what they termed coastal onlap seen in seismic profiles, they calculated that many eustatic oscillations were $100 \mathrm{~m}$ or more. Subsequent research showed, however, that the likelihood of shallow-water sediment accumulating along passive margins depends on the rate of eustatic change in relation to rates of change in sediment supply, basement subsidence, and compaction (Pitman and Golovchenko, 1983). This means that in the absence of detailed age control, compaction history, and paleo-water depth estimates, eustatic magnitudes cannot be derived directly from the architecture of stratal boundaries revealed by seismic profiles (Watts and Thorne, 1984).

Despite an updated eustatic history based, as before, on patterns of coastal onlap, the underlying data was still proprietary (Haq et al., 1987), and researchers saw the need for passive margin records open to public scrutiny (Imbrie et al., 1987; Watkins and Mountain, 1990.) After many locations were evaluated, a transect across the New Jersey (NJ) coastal plain, shelf, and slope was chosen because of its relatively thick and continuous mid- to late-Tertiary section, lack of tectonic disturbance, wealth of background information, and mid-latitude setting that suggested a strong likelihood of yielding excellent geochronology and paleobathymetric control.

\section{IODP Expedition 313 Background}

Ocean Drilling Program (ODP) Leg 150 (Mountain et al., 1994), benfited from earlier drilling (Deep Sea Drilling Project (DSDP) Legs 11 and 95; Hollister et al., 1972; Poag et al., 1987), and was the first step in the multi-leg New Jersey Transect designed to recover a record of eustatic history
(Fig. 1). Leg 150 sampling was limited to the continental slope and rise, but it proved that sequence boundaries, defined by facies successions identified in cores and tied to seismic unconformities, coincided with increases in $\delta^{18} \mathrm{O}$ that formed during times of glacio-eustatic lowering. Due to the distance from paleo-shorelines, these drill cores provided no information about magnitudes of eustatic change. ODP Leg $174 \mathrm{~A}$ on the outer shelf attempted with limited success to sample more proximal Miocene sediments (Austin et al., 1998). Onshore drilling, sponsored by ODP, the International Continental Scientific Drilling Program (ICDP), the U.S. Geological Survey, and the New Jersey Geological Survey, cored equivalent sediments (Miller et al., 1998) and recovered vertical facies associations consistent with glacio-eustatic control. But due to their updip locations, each was stratigraphically incomplete, missing sea-level lowstands and lacking in seismic profiles that would otherwise place all in a broader context of stratal architecture. Nonetheless, calculations that removed the imprint of processes affecting the accumulation of Oligocene-Miocene sediments left 30-50 m sea-level changes that were assumed to be eustatic (Van Sickel et al., 2004). Offshore high-resolution profiles collected in 1995 and 1998 (Mountain et al., 2007; Monteverde et al., 2008) located clinoform topsets, foresets, and toesets of presumed Oligocene-Miocene age that, if sampled, would capture several complete Icehouse sea-level cycles. With the development of mission-specific operations in the IODP, three sites were selected in 2005 and placed on the schedule for drilling from a jack-up platform. It took until 2009 to secure a lift boat (L/B), drill rig, and crew under contract to the European Consortium for Ocean Research Drilling (ECORD) Science Operator (ESO) (Fig. 2). 


\section{Scientific Objectives}

Encouraged by the relatively well-known geologic setting of the NJ transect, and equipped with a platform immune to vertical and lateral motion and a drill rig well-suited for coring in sand-prone formations, Expedition 313 set out to overcome these challenges with the following objectives:

- Compare the age of Oligocene-Miocene Icehouse base-level changes with the age of sea-level lowerings predicted by the global $\delta^{18} \mathrm{O}$ glacio-eustatic proxy

- Estimate amplitudes and rates and infer mechanisms of eustatic sea-level changes

- Evaluate models that predict lithofacies successions, depositional environments, and the arrangement of seismic reflections in response to eustatic change

- Provide a database to compare to sea-level studies on other margins

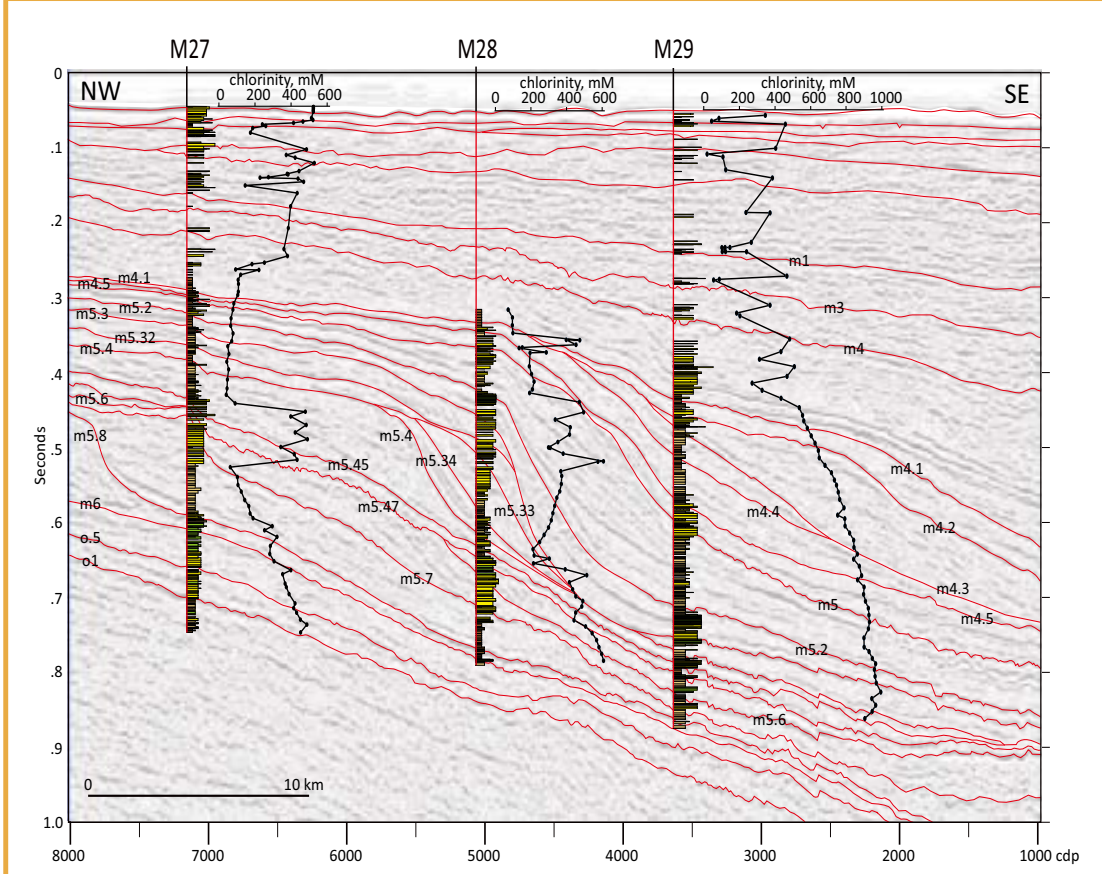

Seismic profile Oc270 line 529 that crosses the three Expedition 313 drill sites. Sediments between key Oligocene-Miocene sequence boundaries (labeled) and other mappable surfaces shown in red comprise many of the drilling targets. Recovered lithofacies (grain size in major units increases from left to right) and pore water chloride concentration are shown in travel time based on our preliminary acoustic travel time to depth-in-hole conversion.

\section{Operations}

The L/B Kayd (owned and operated by Montco Offshore, Inc.) sailed north from the Gulf of Mexico and arrived in Atlantic City where offshore operations mobilized under contract to Drilling, Observation and Sampling of the Earth's Continental Crust (DOSECC). Operations began $45 \mathrm{~km}$ offshore on 30 April 2009 and continued until the return and demobilization at Atlantic City on 19 July 2009 (Table 1).

At each site conductor pipe was run $12-25 \mathrm{~m}$ into the seabed to stabilize the top of the hole and provide re-entry into the seabed for subsequent operations. Various biodegradable drilling fluids were used to condition the hole, cool the drill bit, and lift cuttings to perforations in the casing in the water column from which they settled out onto the seabed. Drilling and coring were conducted with 114.3-mm-diameter PHD drill pipe and top drive assembly commonly used in onshore mining operations. Hydraulic piston and extended-nose rotary coring similar to operations on the JOIDES Resolution were employed, but it was drilling with the extended, rotating coring "Alien" bit developed by DOSECC that proved most successful. Although the drill pipe became stuck numerous times, we had to abandon hope of freeing it only once (at 404 meters below seafloor [mbsf] in Hole 28A). In this case, narrower diameter (96-mm) HQ pipe and extended-nose rotary drilling continued to total depth through the center of the fixed PHD pipe. As anticipated in pre-expedition planning, to maximize operational time in the intervals of highest expedition priorities, we chose to spot core the top 180-220 mbsf at each site (Fig. 3). Five types of wireline electric and imaging logs plus a Vertical Seismic Profile (VSP) were collected in segments at each site (Table 2, Fig. 4).

The onboard complement typically comprised the following personnel: 10 Kayd crew, 7-9 DOSECC drillers, 13-15 ESO staff, and 4-5 expedition science party members. Basic core curation, through-liner descriptions, measurements of ephemeral properties on un-splitcores using the Multi-Sensor Core Logger (MSCL), and sampling at liner boundaries were conducted around the clock for the duration of offshore operations (Table 2).

1. Expedition 313 Operations Summary (mbsl: meters below sea-level; mbsf: meters below seafloor)

\begin{tabular}{|c|c|c|c|c|c|c|c|c|c|c|}
\hline Hole & $\begin{array}{l}\text { Latitude } \\
\text { (N) }\end{array}$ & $\begin{array}{l}\text { Longitude } \\
\text { (W) }\end{array}$ & $\begin{array}{l}\text { Water } \\
\text { Depth } \\
\text { (mbsl) }\end{array}$ & $\begin{array}{l}\text { No. } \\
\text { Cores }\end{array}$ & $\begin{array}{l}\text { Total } \\
\text { Hole } \\
\text { Drilled } \\
\text { (mbsf) }\end{array}$ & $\begin{array}{c}\text { Total } \\
\text { Core } \\
\text { Attempted } \\
(\mathrm{m})\end{array}$ & $\begin{array}{c}\text { Total } \\
\text { Core } \\
\text { Recovered } \\
(\mathrm{m})\end{array}$ & $\begin{array}{c}\text { Total } \\
\text { Core } \\
\text { Recovered } \\
(\%)\end{array}$ & $\begin{array}{c}\text { Total } \\
\text { Hole } \\
\text { Recovered } \\
(\%)\end{array}$ & $\begin{array}{l}\text { Time } \\
\text { on Site } \\
\text { (days) }\end{array}$ \\
\hline M0027A & $39^{\circ} 38.046067^{\prime}$ & $73^{\circ} 37.301460^{\prime}$ & 34 & 224 & 631.01 & 547.01 & 471.59 & 86.21 & 74.74 & 22 \\
\hline M0028A & $39^{\circ} 33.942790^{\prime}$ & $73^{\circ} 29.834810^{\prime}$ & 35 & 171 & 668.66 & 476.97 & 385.5 & 80.82 & 57.65 & 28.7 \\
\hline M0029A & $39^{\circ} 31.170500^{\prime}$ & $73^{\circ} 24.792500^{\prime}$ & 36 & 217 & 754.55 & 609.44 & 454.31 & 74.55 & 60.04 & 26.3 \\
\hline Totals & & & & 612 & 2054.22 & 1633.42 & 1311.4 & 80.29 & 63.77 & 77 \\
\hline
\end{tabular}




\begin{tabular}{|c|c|c|c|}
\hline & L/B Kayd, Offshore New Jersey & Onshore Science Party, Bremen & Moratorium Studies \\
\hline 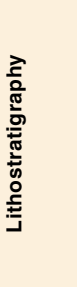 & $\begin{array}{l}\text { Core catcher description } \\
\text { Smear slide identification } \\
\text { Core catcher photography }\end{array}$ & $\begin{array}{l}\text { Split-core visual description archived } \\
\text { according to IODP protocol } \\
\text { Smear slides, thin sections, CT scans } \\
\text { Observations incorporated into facies model } \\
\text { Full core \& close-up photography }\end{array}$ & $\begin{array}{l}\text { Lithofacies (petrography, sedimentary structures, etc.), } \\
\text { depositional environment \& sequence stratigraphic analysis } \\
\text { Ichnofacies \& benthic macrofauna } \\
\text { Diagenetic alteration \& cementation } \\
\text { Compaction \& dewatering } \\
\text { CT scan analysis of sediment structure \& texture } \\
\text { Semiquantitative petrography of coarse sediment } \\
\text { Quantitative clay mineralogy } \\
\text { Mapping Pleistocene valleys }\end{array}$ \\
\hline 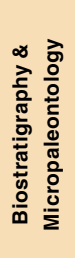 & $\begin{array}{l}\text { Many samples (forams, palynomorphs, } \\
\text { nannos) were taken from core catchers } \\
\text { \& some were analyzed before OSP }\end{array}$ & $\begin{array}{l}\text { Additional sampling \& sample preparation } \\
\text { (primarily nannos, some forams \& } \\
\text { palynomorphs samples) } \\
\text { Biostratigraphic analysis of nannos, planktonic } \\
\text { forams \& dinocysts } \\
\text { Benthic forams paleobathymetry } \\
\text { Palynology paleoenvironments }\end{array}$ & $\begin{array}{l}\text { Semiquantitative nannofossil biostratigraphy \& paleoecology } \\
\text { Controls on planktonic foram abundance \& diversity } \\
\text { Palynomorph taphonomy } \\
\text { Climate \& sea-level controls on ecosystem evolution based } \\
\text { on pollen (Eocene-Miocene) } \\
\text { Diatom \& silicoflagellate biostratigraphy (mid-upper Miocene) } \\
\text { Amino acid racemization age dating (Pleistocene molluscs) } \\
\text { Radiolarian biostratigraphy }\end{array}$ \\
\hline 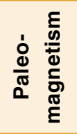 & & $\begin{array}{l}\text { Discrete measurements in fine-grained } \\
\text { sediment } \\
\text { U-channel sampling }\end{array}$ & $\begin{array}{l}\text { U-channel sample measurement \& analysis } \\
\text { Detailed magnetic stratigraphy of selected sections (O/M } \\
\text { transition, clinoform tops, etc.) }\end{array}$ \\
\hline ஸे $\stackrel{\mathscr{0}}{\stackrel{\circ}{\circ}}$ & $\begin{array}{l}300 \text { core catcher samples with shell } \\
\text { material \& benthic forams dated (using } \\
\text { Sr) before OSP }\end{array}$ & Additional 900 samples taken & $\begin{array}{l}{ }^{87} \mathrm{Sr} /^{86} \mathrm{Sr} \text { age dating of } 900 \text { samples of mollusks \& benthic } \\
\text { forams }\end{array}$ \\
\hline 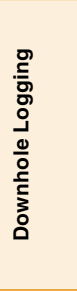 & $\begin{array}{l}\text { Wireline logs, through pipe: } \\
\text { Spectral gamma ray (98\%) } \\
\text { VSP ( } 71 \%) \\
\text { Wireline logs, open hole: } \\
\text { Spectral gamma ray ( } 35 \%) \\
\text { Induction resistivity ( } 46 \%) \\
\text { Magnetic susceptibility ( } 47 \%) \\
\text { Full waveform sonic ( } 34 \%) \\
\text { Acoustic imaging \& caliper (34\%) }\end{array}$ & & $\begin{array}{l}\text { Refine VSP data to use up- \& down-going energy for core- } \\
\text { seismic correlation } \\
\text { Integration of acoustic images, depositional fabric \& CT } \\
\text { scans for core-log correlation } \\
\text { Synthetic seismograms \& core-log-seismic correlation } \\
\text { Statistical analysis of log character \& ties to lithofacies }\end{array}$ \\
\hline $\begin{array}{l}\frac{0}{0} \\
\frac{0}{c} \\
\frac{0}{0} \\
\frac{2}{0} \\
0 \\
0\end{array}$ & & $\begin{array}{l}\text { Discrete sample index properties: } \\
\text { Compressional P-wave velocity } \\
\text { Bulk, dry \& grain density } \\
\text { Water content } \\
\text { Porosity \& void ratio }\end{array}$ & $\begin{array}{l}\text { Changes of permeability, porosity \& thermal conductivity } \\
\text { with depth } \\
\text { Magnetic mineralogy \& links to MSCL data } \\
\text { Cross plots of petrophysical data }\end{array}$ \\
\hline 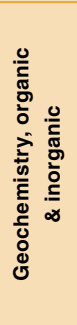 & $\begin{array}{l}\text { Pore water extraction with rhizome or } \\
\text { hydraulic press: } \\
\text { Ephemeral } \mathrm{pH} \text { by ion-specific } \\
\text { electrode } \\
\text { Alkalinity by single-point titration to } \mathrm{pH} \\
\text { Ammonium by conductivity } \\
\text { Chlorinity by automated } \\
\text { electrochemical titration } \\
\text { Headspace samples for methane \& } \\
\text { stable carbon isotopes }\end{array}$ & $\begin{array}{l}\text { IW analysis by ICP-AES \& ICP-MS for } 24 \text { major } \\
\text { \& trace elements } \\
\text { Sediment TOC, TC, \& TS by LECO (carbon- } \\
\text { sulfur analyzer) } \\
\text { Sediment mineralogy by XRD ( } 28 \text { samples) }\end{array}$ & $\begin{array}{l}\text { Relationship of sea-level change to phosphorus \& organic } \\
\text { carbon burial } \\
\text { Stable isotope (C, O, S) geochemistry of sediments } \\
\text { Nd \& Os in sediment pore fluids } \\
\text { Quantitative assessment \& carbon isotope stratigraphy of } \\
\text { organic material (phytoclasts) } \\
\text { Iron-rich chlorite precursors in ichnofabrics } \\
\text { Full suite of elemental analyses \& C isotopes of pore waters } \\
\text { Carbonates \& other authigenic minerals } \\
37 \mathrm{Cl} \& \text { origin of sediment porewater }\end{array}$ \\
\hline 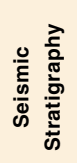 & $\begin{array}{l}\text { Travel-time depth below sea floor } \\
\text { relationship based on stacking } \\
\text { velocities used as preliminary core- } \\
\text { log-seismic correlation }\end{array}$ & $\begin{array}{l}\text { Refined seismic-core correlations to improve } \\
\text { agreement with lithostratigraphy \& physical } \\
\text { properties }\end{array}$ & $\begin{array}{l}\text { Backstripping } \mathrm{NJ} \text { transect compaction \& subsidence history } \\
\text { to estimate eustasy } \\
\text { Mapping seismic sequences on the } \mathrm{NJ} \text { margin with ties to } \\
\text { boreholes }\end{array}$ \\
\hline $\begin{array}{l}\text { 흐 } \\
\frac{0}{0} \\
\frac{0}{0} \\
\frac{0}{0} \\
\frac{0}{2}\end{array}$ & $\begin{array}{l}\text { Sampling \& preparation of sediment } \\
\text { samples }\end{array}$ & & $\begin{array}{l}\text { Identification \& quantification of phylogenetic groups of } \\
\text { microorganisms (microscopic \& molecular techniques) living } \\
\text { in the subsurface }\end{array}$ \\
\hline
\end{tabular}

Note: L/B, lift boat; CT, computed tomography; OSP, Onshore Science Party; O/M transition, Oligocene-Miocene transition; Sr, strontium; VSP, Vertical Seismic Profile; MSCL, Multi Sensor Core Logger; IW, interstitial water; ICP-AES \& MS, Inductively Coupled Plasma Atomic Emission Spectroscopy \& Mass Spectrometry; TOC, Total Organic Carbon; TC, Total Carbon; TS, Total Sulfur; XRD, X-Ray Diffraction; C, O, S, carbon, oxygen, sulfur; Nd, Os, Cl, neodymium, osmium, chloride. Numbers in parentheses equal percentage of total drilled section that was logged. 
All cores and data were transferred to the Bremen Core Repository (BCR) at the end of the offshore phase. Additional measurements of natural gamma radiation, thermal conductivity, and computed tomography (CT) scans on selected cores were performed prior to splitting at the Onshore Science Party (OSP). The entire 28-member science party plus 37 others from the ESO and BCR plus student helpers met at the BCR from 6 November to 4 December 2009 to split, sample, and analyze the 612 cores and logs collected offshore (Table 2).

\section{Preliminary Results}

Drilled-through and recovered sands. Interpreting the results of Exp. 313 began aboard the L/B Kayd by correlating the driller's reports of subsurface conditions with through-liner core descriptions, core-catcher samples, whole-round MCSL measurements, and inferences derived from seismic profiles (Fig. 3). The first strong reflector within a few tens of milliseconds below the seabed at each site indicated fine-grained, relatively firm sediment that provided a stable base for the conductor pipe designed to keep loose surficial sediment from caving into the hole.

The uppermost $\sim 168-220$ mbsf at all three sites contained few strong and continuous reflectors that would indicate regional stratal boundaries of interest and primary coring targets. Although we tried to core continuously in this shallowest interval at Site M27, unconsolidated and coarse-grained sediments led to slow difficult drilling and poor core recovery. This forced the eventual decision to drill without coring until we calculated we were approaching high-priority objectives. The equivalent stratigraphic units (based on seismic correlation) were drilled without coring at Site M28 and were only spot cored at Site M29; all information indicates these were upper Miocene to upper Pleistocene sands and gravels (we identified no Pliocene at any site) deposited in a range of shoreface, estuarine, fluvial, incised valley, and coastal plain environments. A possible paleosol was recovered in this spot-cored interval at Sites M27 and M29 at the depth calculated at both sites to correspond to seismic reflector $\mathrm{m} 1$.

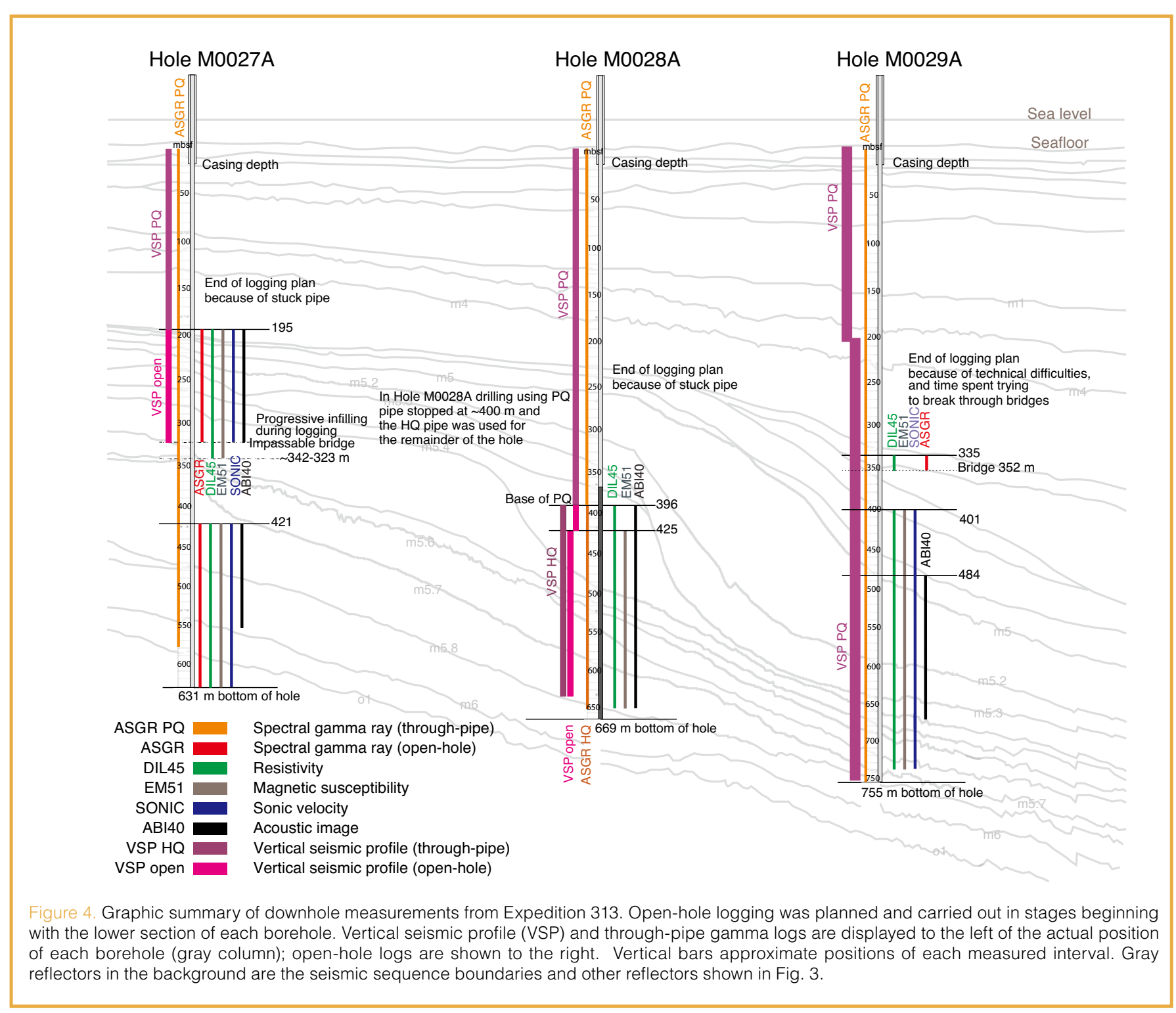




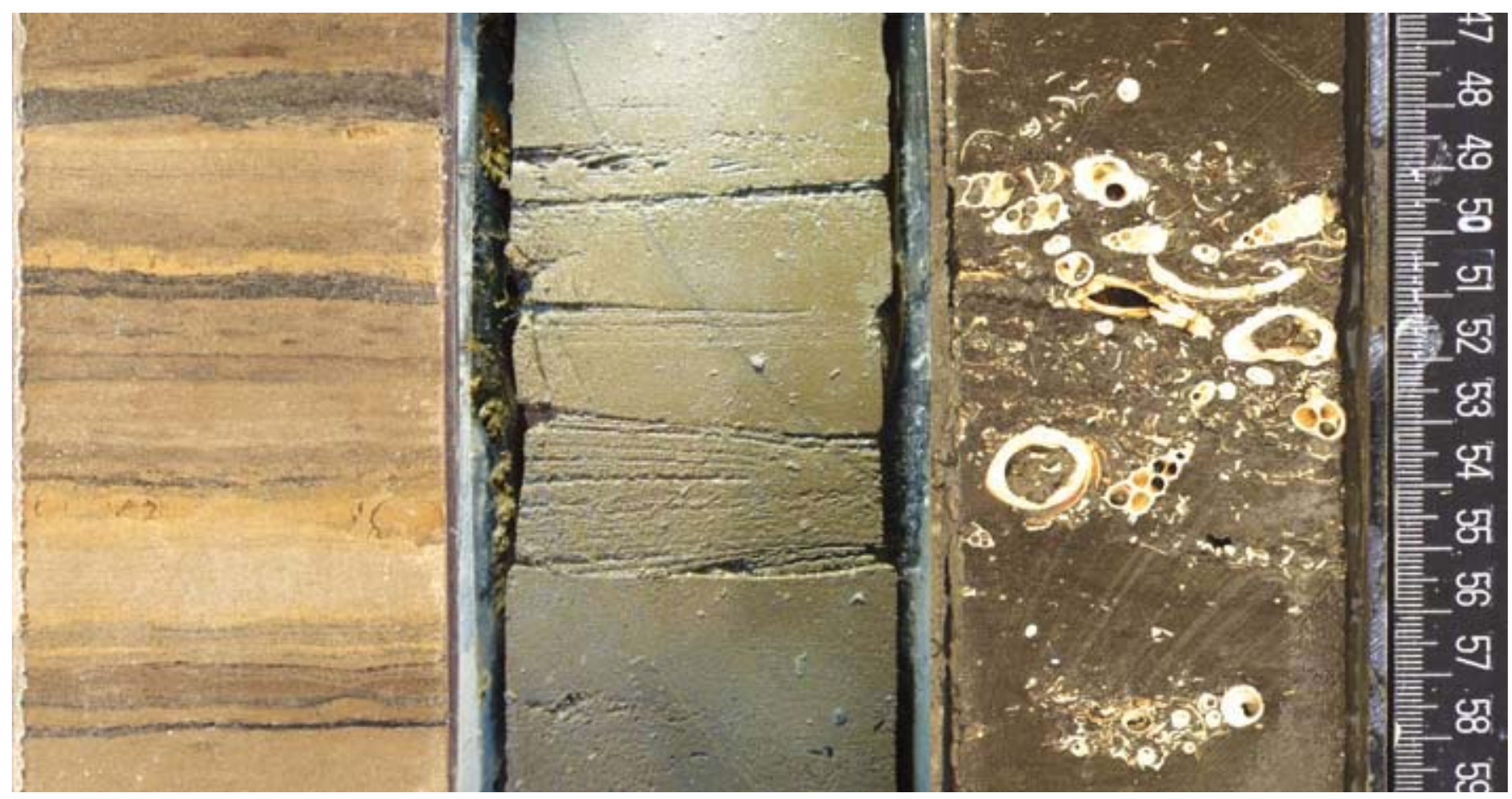

Close-up photographs of 3 split cores showing (from left to right): laminated silty clay from toeset beds seaward of a clinoform (Hole 28 core $166 \mathrm{sec}$ 2); sharp-based sandy storm bed in sandy silt from topset beds (Hole 28 core 92 sec 1); and well-preserved gastropod and mollusk shells in silty offshore flooding surface (Hole 27 core $89 \mathrm{sec} 1$ ).

Integrated seismic, log, and core information. Prior seismic stratigraphy studies (Greenlee et al., 1992; Monteverde et al., 2008) identified probable sequence boundaries on the basis of seismic onlap/offlap patterns and ties to drill cores on the continental slope (Mountain et al., 1994). As a first approximation, stacking velocities from the processing of seismic data surrounding and passing through Exp. 313 sites were used to derive an acoustic travel time to depth-below-seafloor conversion. Check-shot VSP measurements at each site, plus physical properties measurements and synthetic seismograms, will firm up these preliminary seismic-core correlations in subsequent shore-based study.

As many as fifteen regionally mapped reflectors were intersected by one or more Exp. 313 drill sites (Fig. 3). Calculations using our preliminary time-depth equation provided expectations of depths at which surfaces and/or facies changes would be encountered, and typically these came within 5-10 $\mathrm{m}$ of a probable match in the cores, wireline logs, and/or MSCL measurements. In cases where seismic reflectors were especially closely spaced (vertical separation of $<5 \mathrm{~m}$ ), there remains uncertainty concerning which reflector ties to which geologic feature. Future work planned by the Exp. 313 science party will improve the reliability of correlations.

Petrophysical, MSCL, and downhole log data provided additional lithofacies characterization and greatly aided intersite correlations (Fig. 4). By providing continuous data for intervals with poor core recovery, logs enabled us to assign with reasonable confidence major seismic reflectors to depths where there was no core and hence no lithofacies feature to examine.

Described and interpreted the lithofacies. Sediments have been assigned to eight lithostratigraphic units that were deposited under two broadly defined conditions: (1) on a mixed wave- to river-dominated shelf where well-sorted silt and sand accumulated in offshore to shoreface environments and (2) during intervals of clinoform slope degradation that resulted in the interbedding of poorly sorted silts plus debris flow and turbidite sands with toe-of-slope silt and silty clays (Fig. 5). Deposits at all sites and all ages indicate a silt-rich sediment supply notably lacking in clay-sized components. Both in situ and reworked glauconite were common components of top-set and toe-set strata. The open shelf experienced frequent and sometimes cyclic periods of dysoxia. We found no evidence of subaerial exposure at the clinoform inflection point (depositional shelf break), but the periodic occurrences of shallow-water facies along clinoform slopes and of deepwater facies on the topset of the clinoforms suggest large-amplitude changes in relative sea level. Backstripping will provide estimates of the true eustatic component involved in the $\sim 60-\mathrm{m}$ changes in relative sea level observed on the shelf.

Developed geochonology of the sedimentary record. 1) Biostratigraphy: Roughly 300 samples were taken from core catchers on the Kayd and brought ashore for extraction of suitable mollusk shells and forams for Sr isotopic dating prior to the OSP in Bremen. Additional samples for palynomorphs, foraminifera, and calcareous nannofossils were also 
collected offshore and prepared prior to the OSP. Additional biostratigraphic control available at this preliminary stage comes largely from calcareous nannofossils sampled in split cores and analyzed during the OSP; as time allowed, a limited number of additional samples for planktonic foraminifera and palynomorphs were prepared and analyzed in Bremen. Additional biostratigraphic shore-based studies will be performed using diatoms and radiolaria. Amino acid racemization studies will be conducted on shells from the upper few tens of mbsf at Sites M27 and M29.

2) Magnetostratigraphy: Due to the paucity of fine-grained intervals and/or the lack of carrier minerals preserving a remnant signal, geomagnetic reversal chronology measured during the OSP was restricted to a few short intervals. More sensitive and time-consuming demagnetization techniques on discrete samples, as well as on U-channel samples, will be applied during post-OSP studies and may contribute further to Exp. 313 geochronology.

3) Sr isotopes: There is generally good agreement between the biohorizons of the different microfossil groups and the Sr isotope ages. One exception is within the thick Oligocene section at Site M27 where more shore-based analysis is warranted. The abundance and preservation of calcareous microfossils and dinocysts vary significantly, with barren intervals coinciding with coarse-grained sediments. Sr isotopic measurements provided ages that approached a precision of \pm 0.5 m.y. in some intervals and \pm 1 m.y. in others. A notable exception was the middle Miocene silty clay at Site M29 that showed substantial scatter. Microfossils are most abundant in this latter, most distal site, allowing for age refinements within the lower Miocene sections that proved barren of planktonic microfossils at the more proximal sites. Reworked Paleogene material occurs throughout the Miocene at all sites. A preliminary age-depth plot was developed in Bremen (Fig. 6) and will be refined when these additional shore-based studies are complete.

\section{Detected sea-level changes and paleoclimate.} Paleobathymetry and paleoenvironments determined from benthic foraminifers, dinocysts, and terrigenous palynomorphs track similar paleodepth variations at each site and in general agree well with paleobathymetric changes indicated by lithofacies. Values at each site range from inner neritic $(0-50 \mathrm{~m})$ to outer neritic $(100-200 \mathrm{~m})$. Paleodepth variations within individual unconformity-bound topset intervals suggest relative sea-level changes were as large as $60 \mathrm{~m}$. While we detected mass failure of clinoform foresets, we found no evidence that sea level ever fell below the elevation of clinoform topsets. Water depth estimates based on benthic for-aminifers and palynological estimates of proximity to the shoreline show good to excellent agreement at all sites. Pollen studies identified a hemlock horizon across all three sites, indicating temperate forests and humid conditions on the Atlantic coastal plain during the early Miocene. Middle Miocene pollen assemblages record the expansion of grasses and sedges, indicating increasing aridity.

Analyzed pore water chemistry. Pore-water studies show that the upper several hundred meters of sediment at each site is dominated by freshwater interlayered with salt water of nearly seawater chlorinity. The abrupt boundaries between fresh and saline pore waters are especially remarkable (Fig. 3); whether they are maintained by dynamic flow/ recharge or by strongly impermeable boundaries is not yet recognized. The pore water in these layers may have chemistries sufficiently distinct to enable correlation of individual layers from site to site; more shore-based analysis is required. Chloride concentrations increase with depth below seafloor, 
reaching seawater values in Site M27 and even higher concentrations in the other two sites. In Site M29, brine was encountered toward the bottom of the hole, reaching a chlorinity value twice that of seawater.

\section{Acknowledgements}

We are grateful to Dennis Nielson, Chris Delahunty, Beau Marshall, and the rest of the DOSECC drilling team, to Captains Clem Darda and Farrel Charpentier plus the crew of the L/B Kayd, to Dan Evans, David Smith, Colin Graham, David McInroy, Carol Cotterill, and the rest of the very talented ESO support staff of the mission-specific operations for ECORD, and to Ursula Röhl, Holger Kuhlmann, and the BCR staff in Bremen. Without these individuals and the many others left unnamed, the New Jersey Shallow Shelf operations would not have been possible. Two decades of preparatory and related studies were supported by grants from the U.S. National Science Foundation's Division of Ocean Sciences as well as the Division of Earth Sciences, the U.S. Office of Naval Research, the U.S. Geological Survey, and the New Jersey State Geological Survey. IODP funds were augmented by a long-standing commitment from ICDP, for which we are grateful.

\section{References}

Austin, J.A., Jr., Christie-Blick, N., Malone, M.J., Berné, S., Borre, M.K., Claypool, G., Damuth, J., Delius, H., Dickens, G., Flemings, P., Fulthorpe, C., Hesselbo, S., Hoyanagi, K., Katz, M., Krawinkel, H., Major, C., McCarthy, F., McHugh, C., Mountain, G., Oda, H., Olson, H., Pirmez, C., Savrda, C., Smart, C., Sohl, L., Vanderaveroet, P., Wei, W., Whiting, B., 1998. Proc. ODP, Init. Repts., 174A: College Station, TX (Ocean Drilling Program).

Bard, E., Hamelin, B., Arnold, M., Montaggioni, L., Cabioch, G., Faure, G., and Rougerie, F., 1996. Deglacial sea-level record from Tahiti corals and the timing of global meltwater discharge. Nature, 382:24-244; doi:10.1038/382241a0.

Berggren, W.A., and Pearson, P.N., 2005. A revised tropical to subtropical Paleogene planktonic foraminiferal zonation. J. Foram. Res., 35(4):279-298. doi:10.2113/35.4.279.

Berggren, W.A., Kent, D.V., Swisher, C.C., III, and Aubry, M.-P., 1995. A revised Cenozoic geochronology and chronostratigraphy. In Berggren, W.A., Kent, D.V., Aubry, M.-P., and Hardenbol, J. (Eds.), Geochronology, Time Scales and Global Stratigraphic Correlation. Spec. Publ. - SEPM (Society for Sedimentary Geology), 54:129-212.

Camoin, G.F., Iryu, Y., McInroy, D., and the IODP Expedition 310 Scientists, 2007. IODP Expedition 310 reconstructs sea level, climatic, and environmental changes in the South Pacific during the last deglaciation. Sci. Drill., 5:4-12; doi:10.2204/iodp.sd.5.01.2007.

Cande, S.C., and Kent, D.V., 1995. Revised calibration of the geomagnetic polarity timescale for the Late Cretaceous and Cenozoic. J. Geophys. Res., 100(B4):6093-6095. doi:10.1029/94JB03098.
De Verteuil, L. and Norris, G., 1996. Miocene dinoflagellate stratigraphy and systematics of Maryland and Virginia. Micropaleontology, 42, supp., part 1:1-82.

Fairbanks, R.G., 1989. A 17,000-year glacio-eustatic sea level record: influence of glacial melting rates on the Younger Dryas eventanddeep-oceancirculation.Nature,342(6250):637-642, doi:10.1038/342637a0.

Greenlee, S.M., Devlin, W.J., Miller, K.G., Mountain, G.S., and Flemings, P.B., 1992. Integrated sequence stratigraphy of Neogene deposits, New Jersey continental shelf and slope: comparison with the Exxon model. Geol. Soc. Am. Bull., 104(11):1403-1411, doi:10.1130/0016-7606(1992)104<1403: ISSOND $>2.3 . \mathrm{CO} ; 2$.

Harrison, C.G.A., 1990. Long-term eustasy and epeirogeny in continents. In Revelle, R. (Ed.), Sea-level Change: Washington, DC (National Academy Press), 141-158.

Haq, B.U., Hardenbol, J., and Vail, P.R., 1987. Chronology of fluctuating sealevelssincetheTriassic.Science,235(4793):1156-1167, doi:10.1126/science.235.4793.1156.

Hays, J.D., and Pitman, W.C., III, 1973. Lithospheric plate motion, sea level changes and climatic and ecological consequences. Nature, 246(5427):18-22, doi:10.1038/246018a0.

Hollister, C.D., Ewing, J.I., Hathaway, J.C., Lancelot, Y., Paulus, F.J., Habib, D., Luterbacher, H., Poag, C.W., Wilcoxon, J.A., Worstell, P., 1972. Init. Repts. DSDP, 11: Washington, DC (U.S. Govt. Printing Office).

Imbrie, J., Barron, E.J., Berger, W.H., Bornhold, B.D., Cita Sironi, M.B., Dieter-Haass, L., Elderfield, H., Fischer, A., Lancelot, Y., Prell, W.L., Togweiler, J.R., and Van Hinte, J., 1987. Scientific goals of an Ocean Drilling Program designed to investigate changes in the global environment. In Munsch, G.B. (Ed.), Report of the Second Conference on Scientific Ocean Drilling (COSOD II): Strasbourg (European Science Foundation), 15-46.

Kominz, M., 1984. Oceanic ridge volumes and sea-level change: an error analysis. In Schlee, J.S. (Ed.), Interregional Unconformities and Hydrocarbon Accumulation, AAPG Mem., 36:109-127.

Martini, E., 1971. Standard Tertiary and Quaternary calcareous nannoplankton zonation. In Farinacci, A. (Ed.), Proc. 2nd Int. Conf. Planktonic Microfossils Roma: Rome (Ed. Tecnosci.), 2:739-785.

Miller, K.G., Mountain, G.S., Browning, J.V., Kominz, M., Sugarman, P.J., Christie-Blick, N., Katz, M.E., and Wright, J.D., 1998. Cenozoic global sea level, sequences, and the New Jersey transect: results from coastal plain and continental slope drilling. Rev. Geophys., 36(4):569-602, doi:10.1029/98RG 01624.

Monteverde, D., Mountain, G., and Miller, K., 2008. Early Miocene sequence development across the New Jersey margin. Basin Res., 20:249-267, doi:10.1111/j.1365-2117.2008. 00351.x.

Mountain, G.S., Burger, R.L., Delius, H., Fulthorpe, C.S., Austin, J.A., Goldberg, D.S., Steckler, M.S., McHugh, C.M., Miller, K.G., Monteverde, D.H., Orange, D.L., and Pratson, L.F., 2007. The long-term stratigraphic record on continental margins. In Nittrouer, C.A., Austin, J.A., Jr., Field, M.E., Kravitz, J.H., 
Syvitski, J.P.M., and Wiberg, P.L. (Eds.), Continental Margin Sedimentation: From Sediment Transport to Sequence Stratigraphy, IAS Spec. Publ., 37: Oxford (Blackwell Publishing Ltd.), 381-458.

Mountain, G.S., Miller, K.G., Blum, P., et al., 1994. Proc. ODP, Init. Repts., 150: College Station, TX (Ocean Drilling Program).

Pitman, W.C., III, and Golovchenko, X., 1983. The effect of sea level change on the shelf edge and slope of passive margins. Spec. Publ.-Soc. Econ. Paleontol. Mineral., 33:41-58.

Poag, C., Watts A.B., et al., 1987. Init. Repts. DSDP, 95: Washington, DC, (U.S. Govt. Printing Office), doi:10.2973/dsdp. proc.95.1987.

Rahmstorf, S., 2007. A semi-empirical approach to projecting future sea-level rise. Science, 315(5810):368-370, doi:10.1126/ science. 1135456 .

Sloss, L.L., 1963. Sequences in the cratonic interior of North America. GSA Bulletin, 74(2):93-114; doi:10.1130/0016-7606(1963) 74[93:SITCIO]2.0.CO;2.

Solomon, S., Qin, D., Manning, M., Chen, Z., Marquis, M., Averyt, K.B., Tignor, M., and Miller, H.L. (Eds.), 2007. Contribution of Working Group I to the Fourth Assessment Report of the Intergovernmental Panel on Climate Change: Cambridge, U.K. and New York, U.S. (Cambridge University Press).

Vail, P.R., Mitchum, R.M., Jr., and Thompson, S., III, 1977. Seismic stratigraphy and global changes of sea level, Part 2 . The depositional sequence as a basic unit for stratigraphic analysis. In Payton, C.E. (Ed.), Seismic Stratigraphy: Applications to Hydrocarbon Exploration, AAPG Mem., 26:53-62.

Van Sickel, W.A., Kominz, M.A., Miller, K.G., and Browning, J.V., 2004. Late Cretaceous and Cenozoic sea-level estimates: backstripping analysis of borehole data, onshore New Jersey. Basin Res., 16:451-465, doi:10.1111/j.1365-2117. 2004.00242.x.

Watkins, J.S., and Mountain, G.S., 1990. Role of ODP drilling in the investigation of global changes in sea level. Report of a JOI/USSAC Workshop, El Paso, Texas, 24-26 October 1988, $70 \mathrm{pp}$.

Watts, A.B., and Steckler, M.S., 1979. Subsidence and eustasy at the continental margin of eastern North America. In Talwani, M., Hay, W., and Ryan, W.B.F. (Eds.), Deep Drilling Results in the Atlantic Ocean: Continental Margins and Paleoenvironment: Washington, DC (American Geo-physical Union), 218-234.

Watts, A.B., and Thorne, J.A., 1984. Tectonics, global changes in sea-level and their relationship to stratigraphic sequences at the U.S. Atlantic continental margin. Mar. Pet. Geology, 1:319-339, doi:10.1016/0264-8172(84)90134-X.

\section{Authors}

Gregory Mountain (Co-chief Scientist), Department of Earth and Planetary Sciences, Rutgers University, 610 Taylor Road, Piscataway, NJ 08854, U.S.A., e-mail: gmtn@rci.rutgers.edu.

Dr. Jean-Noël Proust (Co-chief Scientist), Géosciences, CNRS, Université Rennes1, Campus de Beaulieu, 35042

Rennes, France, e-mail: jean-noel.proust@univ-rennes1.fr.

\section{IODP Expedition 313 Science Party}

Co-Chief Scientists: Gregory Mountain (U.S.), Jean-Noël Proust (France); ESO Staff Scientists: David McInroy (U.K.), Dayton Dove (U.K.); Sedimentologists: Hisao Ando (Japan), James Browning (U.S.), Stephen Hesselbo (U.K.), David Hodgson (U.K.), Marina Rabineau (France), Peter Sugarman (U.S.); Stratigraphic Correlators: Maria-Angela Bassetti (France), Kenneth Miller (U.S.), Donald Monteverde (U.S.); Paleontologists: Baoqi Huang (China), Miriam Katz (U.S.), Ulrich Kotthof (Germany), Denise Kulhanek (U.S.), Francine McCarthy (Canada); Petrophysicists: Jenny Inwood (U.K.), Johanna Lofi (France), Christophe Basile (France,) Christian Bjerrum (Denmark), Hironori Otsuka (Japan), Henna Valppu (Finland); Porewater Geochemists: Takeshi Hayashi (Japan,) Michael Mottl (U.S.); Paleomagneticists: Youn Soo Lee (Korea), Andres Nilsson (Sweden); Microbiologist: Susanne Stadler (Germany)

\section{Related Web Links}

http://www.montco.com

http://www.dosecc.org

http://www.eso.ecord.org/expeditions/313/313.php

http://publications.iodp.org/preliminary_report/313/313_ t1.htm

http://publications.iodp.org/preliminary_report/313/313_ t2.htm

http://publications.iodp.org/scientific_prospectus/313/313 _t5.htm\#1022416

\section{Figures and Photo Credits}

Figure 2. photo cortesy of ESO/IODP

Figure 5. by Gregory Mountain 